УДК 78.03+784.96

Лариса Леонідівна Долинська, здобувач Одеської національної музичної академії ім. А. В. Нежданової

\title{
КОЛЕКТИВНИЙ СПІВ У ДИТЯЧОМУ ФОЛЬКЛОРІ
}

Мета роботи. Стаття пов'язана з дослідженням природи, умов та особливостей функціонування колективного співу у дитячому фольклорі зі спиранням на категорії колективності, гри, цілісності, а також дитинства, дитячості. Методологія дослідження полягає в застосуванні компаративного, естетико-культурологічного, історичного методів, а також музикознавчого аналітичного підходу, які утворюють єдину методологічну основу. Зазначений методологічний підхід дозволяє розкрити модель дитячого колективного співу як специфічного культурного явища у синкретичній системі фольклору. Наукова новизна роботи полягає в розширенні уявлень про дитячий колективний спів у фольклорі у мистецтвознавчому та музикологічному аспектах. Доводяться колективна природа, ігрові засади дитячого співу у фольклорі, іманентність якості цілісності, зв'язок зі смисловим полем дитячості. Висновки. Категорії колективності, гри, иілісності, а також дитинства, дитячості виступають у дитячому фольклорі (поряд з синкретизмом, утилітарністю, символізмом, образністю, декоративністю і традиційністю) тими основними концептами, які визначають його зміст, розвиток, міфологічні й виховальні засади, музично-мовні засоби.

Ключові слова: дитячий фольклор, дитинство, колективний дитячий спів, ігрова природа, цілісність.

Dolinskaya Larisa Leonidovna, The Odessa National A. V. Nezhdanova Academy of Music, applicant of the department of history of music and musical ethnography

Collective singing in children's folklore

Objective. The article deals with the study of the nature, conditions and features of the functioning of collective singing in children's folklore, based on the categories of collectivity, playing, integrity, and childhood, childishness. Methodology of the study deals with the application of comparative, aesthetic-cultural, historical methods, as well as musicological and analytical approach, which form a unified methodological basis. This methodological approach allows us to reveal the model of children's collective singing as a specific cultural phenomenon in the syncretic system of folklore. The scientific novelty of the work is to expand the understanding of children's collective singing in folklore in the art and musicological aspects. The collective nature, playing bases of children's singing in folklore, immanence of integrity quality, connection with the semantic 
field of childishness are being proved. Conclusions. The categories of collectivity, playing, integrity, and childhood, childishness, act in children's folklore (along with syncretism, utilitarianism, symbolism, imagery, decorative and traditional) as those basic concepts that determine its content, development, mythological and educational principles, musical-language facilities.

Keywords: children's folklore, childhood, collective children's singing, playing nature, integrity.

Долинская Лариса Леонидовна, соискатель Одесской национальной музыкальной академии им. А. В. Неждановой

Коллективное пение в детском фольклоре

Цель работы. Статья связана с исследованием природы, условий и особенностей функционирования коллективного пения в детском фольклоре при опоре на категории коллективности, игры, целостности, а также детства, детскости. Методология исследования заключается в применении сравнительного, эстетико-культурологического, исторического методов, а также музыковедческого аналитического подхода, которые образуют единую методологическую основу. Указанный методологический подход позволяет раскрыть модель детского коллективного пения как специфического культурного явления в синкретической системе фольклора. Научная новизна работы заключается в расширении представлений о детском коллективном пении в фольклоре в искусствоведческом и музыкологическом аспектах. Доказываются коллективная природа, игровые основы детского пения в фольклоре, имманентность качества целостности, связь со смысловым полем детскости. Выводы. Категории коллективности, игры, целостности, а также детства, детскости выступают в детском фольклоре (наряду с синкретизмом, утилитарностью, символизмом, образностью, декоративностью и традиционностью) теми основными концептами, которые определяют его содержание, развитие, мифологические и воспитательные принципы, музыкально-языковые средства.

Ключевые слова: детский фольклор, детство, коллективное детское пение, игровая природа, целостность.

Актуальність теми дослідження. Тема дитинства, дитячості, «відкриття дитинства» сьогодні постає мало не «загальним місцем» у дослідженнях найрізноманітніших наукових спеціалізацій та напрямків. Це не дивно, адже саме у наш час вказані аспекти буття, мистецтва й науки віддзеркалюють сучасне прискорення у часі з необхідністю посилення освітньо-виховних функцій швидкоплинного процесу дорослішання. 3 іншого боку, все глибше, ширше й «тонше» досліджуються та «підвищуються у ціні» дорослого світу уміння зберегти й, по можливості, упровадити у побутові і духовні шари життя, професійну 
діяльність - цінні ознаки дитячості, як то щирість, чистоту помислів і дій, створювально-продуктивні творчо-ігрові інтенції з іманентними цілісно-позитивними векторами сприйняття, сміливу нестандартну (не обмежену «дорослими» законами і співвідношенням цінностей) фантазійність, продуктивні властивості співпричетності (партиципації) та співпереживання (емпатії) тощо. У цьому відношенні дитяча художня творчість, особливо у такій «безпосередньо-природній» іiї реалізації, як колективний (хоровий) спів (що, наприклад, не потребує «годин удосконалення» за музичним інструментом), виступає найглибшим (не «пошкодженим» корисними мотивами, дорослою гріховністю) та найзручнішим (швидке «включення», необов'язковість додаткових інструментів) втіленням соціально-культурної і смислової цілісності, тобто відповідає соціально-культурним ідеалам колективної емпатії та світовідчуття. Адже «принципи музичного мислення в традиційній культурі можуть базуватися, в тому числі, і на колективному несвідомому i, отже, виявляти глибинні якості, що дозволяють проводити паралелі з явищами іншого соціокультурного та історичного простору» $[10,150] .3$ такої точки зору колективний дитячий спів у фольклорному просторі постає своєрідним символом «у квадраті»: дитинство і дитячість у «дитинстві культури» - продукуючи нові виміри індивідуального становлення людської особистості та колективно-соборного «МИ», пізнання закономірностей художньої «іншомовності» та відкриття справжньої смислової сили людських переживань, а також необхідного у цілісності буття взаємообміну дорослого і дитячого світів, у тому числі освітньо-виховального та духовного порядків. Отже дослідження природи і функціонування вказаного символічного поля створює актуальний шар наукового пізнання, а також є метою даної статті.

Викладення основного матеріалу. Термін «дитячий фольклор» увійшов до наукового вжитку з середини XIX століття, на хвилях загального інтересу педагогів та методистів до народної школи; сприйняття фольклору як матеріалу, що має велику художню та педагогічну цінність і є проводником ідей народності та патріотичного виховання, нарешті - романтичного ідеалізованого «культу дитинства» 3 протиставленням його невинної чистоти та щирої безпосередності «затемненому» дорослими гріхами та розсудливо-холодному світу дорослості. Саме у цей час дитячий фольклор стає органічною частиною кола читання дитини (дворянського та інтелігентського походження, перш за все); матеріалом для друку у збірниках, спеціальних видан- 
нях, книгах для читання, журналах. А у професійній європейській та російській інструментальній музиці відбувається «вибух» дитячих альбомів - музики, адресованої дітям, та дитячої образності.

Дослідження дитячого фольклору в XIX столітті характеризується інтенсивним накопиченням фактичного матеріалу і першими спробами його теоретичного осмислення, обумовленого, перш за все, педагогічно-виховними інтересами. Основний зміст поняття «дитячий фольклор» сформувався вже у двадцяті роки XX століття. До цієї сфери стали відносити твори усної народної словесності, які «призначаються для дітей, та існуючі в дитячому середовищі», а носіями дитячого фольклору визнані самі діти й дорослі, «під опікою яких знаходяться діти або які в силу тих чи інших обставин близькі до дітей» $[4,18]$. Одним $з$ перших науковців 3 дослідження спеціально дитячого фольклору вважається Г. Виноградов, ідеї якого стали основою для формування особливого наукового напрямку - етнографії дитинства. Практично вчений обгрунтував існування дитячої субкультури, де «традиційні норми поведінки, ігрові правила, вербальні формули і тексти передаються всередині групи від старших дітей до молодших без посередництва дорослих» [4, 15], відмовивши у приналежності до дитячого фольклору усьому, що не виконується самими дітьми (колискові, плекання й забавлянки відніс до материнської школи - літератури для дітей). Відомий викладач і дослідниця 20-30-х pp. XX століття О. Капиця, узагальнюючи досвід російських та європейських, зокрема англійських, вчених щодо вивчення жанрів дитячого фольклору, наполягаючи на самобутності дитячої творчості та наукових методах іï дослідження, стверджувала приналежність до дитячого фольклору «усіх творів усної народної творчості, що побутують серед дітей. Носіями і творцями дитячого фольклору є дорослі і діти» [цит. за 7, 6]. Так визначилися жанри дитячого фольклору за функціональним розрізненням (для дітей та виконувані дітьми). У другій половині XX століття В. П. Анікін обгрунтував три історичні напрямки дитячого фольклору - історико-генетичний, філологічний і функціонально-педагогічний, висловивши й ряд цінних зауважень по генезису окремих жанрів. Після вимушеної з ідеологічних причин перерви у вітчизняній науці новий крок у дослідженні дитячої фольклористики зробив М. Мельников (1970, 1987), який, втім, обмежується тезою, що «дитячий фольклор становить специфічну галузь народної творчості, що поєднує світ дітей і світ дорослих, включаючи цілу систему поетичних і музично-поетичних жанрів» [9, 4]). Далі 
Г. Довженок (1986, «коло творів, охоплюваних цим поняттям, широке й багатоманітне - за призначенням, тематикою й образною системою, способом і часом виконання» [3, 5]), М. Осоріна (1991, «вид традиційної колективної усної дитячої творчості, яка реалізується в системі стійких текстів, що передаються з покоління у покоління дітей і мають важливе значення в регуляції їхньої ігрової та комунікативної діяльності в групах одноліток. Ф[ольклор] д[итячий] варто відрізняти від фольклору для дітей (колисанки, забавлянки, утішки, примовки тощо), носіями якого зазвичай є дорослі, які використовують фольклорні тексти для спілкування з маленькою дитиною (заспокоєння, спонукання до дії, розвага, навчання)» $[13,140])$, С. Лойтер (2002, «велика, специфічна, багатоскладна галузь вербальної народної творчості, що включає до себе класичний дитячий фольклор (передусім, «поезію плекання», тобто твори, що створювалися і виконувалися дорослими; фольклорні тексти, носії яких - діти дошкільного віку) і цокольний (низовий. - Л. Д.) фольклор у його усних і письмових формах, в тому числі мовні утворення, що увійшли до дитячої традиції» [7, 8], С. Росовецький (2007, «дитячий фольклор звучить для дітей... його тексти чітко поділяються на три групи: твори, що їх виконують дорослі (головним чином жінки) для дітей; твори дорослих, які виконують самі діти; твори, що їх діти виконують самі, без втручання дорослих» $[15,207])$ - не визначаючи чіткої дефініції дитячого фольклору, окреслюють широке (звужене - М. Осоріна) коло його проблем або типології текстів за різними ознаками. Звичайно, фольклористам зручніше поєднувати під терміном «дитячий фольклор» усі три типи спорідненених за об'єктом спрямованості, віковою орієнтацією та поетичними засобами текстів (як у Ф. Капиці: «дитячий фольклор являє собою складну єдність трьох складових - творчості дорослих для дітей, творів традиційного фольклору дорослих, які перейшли до дитячого середовища, і оригінальної дитячої творчості» $[4,4])$. Нам здається найбільш вдалим визначення О. Марчун (2010): «Дитячий фольклор є складником усної народної творчості взагалі, що твориться за особливими специфічними законами усної передачі від покоління до покоління і має такі ознаки, як усна форма творення й поширення; традиційність; варіантність; анонімність; колективність» $[8,12]$. До специфіки явища, обумовленого особливостями дитячого мислення та емоційної природи дитини з відмінним від дорослих сприйняттям художнього образу, дослідниця відносить також «своєрідність відображення в ньому реального життя, органічне 
сплетення елементів реальності й фантастики, потяг до гри словом, його змістом, звучанням, до таємничості й загадковості» [там само, 14]. Оскільки дитяче світосприйняття є безпосередньо-відкритим, прозорим, сприймаючим навколишній світ у його самонароджуваній «різнокольоровій» багатоплановості, воно природньо відтворює цілісність буття, яка втрачена дорослим світом (принаймні, цивілізованим) у його спробах «продуктивного аналізу» і логікоцентричного вдосконалення. Але ж саме у фольклорі така цілісність буття, спрямована міфологізованими та символізованими архаїчними маркерами, виявляє чи не найбільші ознаки спільності з дитячою. Недаремно фольклор вважається «дитинством культури». Отже, до специфічних ознак дитячого фольклору, вказаних О. Марчун, ми додаємо специфічну цілісність, втілену у власних образно-смислових та мовних (у тому числі музично-мовних) засобах.

Той факт, що дитинство тривалий час сприймалося у суспільстві (общині) тільки як підготовка до дорослого життя, його «нерозвинена», передуюча форма не означає, що дитячість, як певний психологічний стан, стан свідомості, світобачення людини, не існувала як явище, як неусвідомлена якість. Отже логічним видається й існування відповідного особливого типу естетичного сприйняття світу (необхідного чинника цілісності буття), який викликає до життя й власні художні образи, художні прийоми, які відображають саме вказаний тип світосприйняття. Сьогодні вчені вже впевнені, що дитячість (в широкому сенсі слова) є обов'язковою частиною поетичного бачення, втім, з власними, настільки специфічними та рельєфними властивостями, що вони «провокують» ії самостійність, особливого роду художні завдання, з якими вона пов'язана. Але у фольклорному просторі можна виявити первинний дуалізм глибинного розуміння дитинства, який далеко «передує» науково-філософському, цивілізаційному «відкриттю дитинства» Нового часу і зіставляється з подібним дуалізмом у просторі християнської культури. Це виглядає вповні логічним з точки зору вміщення обома сферами первинної якості цілісності буття.

На описаний дуалізм у фольклорі, зокрема, вказує емоційно-ціннісне відношення до дитини «у народі», виявлене у мовно-діалектних номінаціях - «семантичній периферії слова, яка відображає матеріальні і духовні основи побутування народу», у «лінгвокультурологічному портреті дитини» $[17,1]$. У мовній фольклорній актуалізації уявлень про дитину дослідники відзначають різні соціально- 
культурні, родинні, зовнішньофізичні, вікові та інші аспекти ії життя $[17,9-10]$. Якщо відступ від норми у дорослого у мовному вираженні створює певний еталон, наприклад, у зв'язку віку з типом поведінки: «нетяма» - віддзеркалює характерні для дитини простоту, нерозвиненість суджень; «дитячий лепет», «впасти у дитинство» - відхилення від інтелектуальної та поведінкової норми як еталона дорослості, то у дитини такий відступ далеко не завжди маркується негативно: невід'ємним є й специфічне відношення до малечі (наприклад, «мій брудненький» і т.ін.). Традіційний уклад селянського життя, заснований на колективному побутуванні у непростих умовах, соборності громади зумовив сприйняття дітей як нероздільної, позбавленої індивідуальності, статі та віку безлічі, «наслідком чого $є$ позначення, що містять сему збірності: дітвора, дітня», «ідеї малості, стихійності, дикості, пустощів, простоти, тобто характерних рис періоду дитинства» у поєднанні з додатковим експресивним компонентом вираження у вигляді зменшувально-пестливих (дітлахи, дітки, діточки, дитинча, дитинка), образно-метафоричних, з семантикою множинності і маленького розміру (комахи, сарана), найменувань [17, 14-15]. Таким чином, «в лінгвокультурологічному портреті присутня оцінна складова, що створює ціннісну картину світу людини» $[17,10]$ і він відповідає, з одного боку, «офіційній» у фольклорному середовищі, але «поверхневій», концепції про дитину - «неповноцінного дорослого»; 3 іншого - міфілогізованому сприйняттю дитини як представника потойбіччя, що втілюється, зокрема, в експресивно-відмінних, образно-семантичних формулах мовлення. Якщо у цивілізованій міській культурній аурі Нового часу (живопис, християнська культура, освітньо-виховний цикл, література, музика, пізніше - наука) відбувся поворот до «відкриття дитинства», і зараз людство йде до цілісності доросло-дитячого світосприйняття, «навчаючись втраченої дитячості», то у фольклорному просторі таке знання й не потребувало «відкриття», будучи закладеним у первинній видовій цілісності. Якщо у мистецтві, філософії та інших культурних сферах поступово формулювалися й ті автономні смислові інтенції «дитячої теми», що стали здатними до власної знакової предметності, іносказання й відволікання від безпосередньо представлених образів дітей, зокрема, в музичній формі - засобами музичної мови, то у синкретичному цілому фольклору вони містилися відпочатку. 3 трьох визначених В. Конен пластів музики - фольклорного, професійно-академічного, «третього» (який вміщує шари, що не увійшли до перших двох) - перший, 
фольклорний, імпровізаційно-усної, синкретично-ігрової, театралізованої природи, уособлюючий у цілісності подання світоглядноміфологічні інтенції колективного «Ми», є найконсервативнішим (інакше його називають традиційним) з точки зору збереження архаїчних цінностей і мовно-знакових маркерів, але й найбільш вільним з боку неписьмової імпровізаційно-виконавської практики (що справило свій вплив на інші два пласти). Картина світу у свідомості дитини, як і у загальному фольклорному просторі, постає як цілісна і різноманітна модель реальності. Дитина у своєму індивідуальному розвитку проходить в скороченому вигляді всі етапи еволюції розуміння навколишнього світу і засвоює знання про нього - перш за все, у родинно-громадському середовищі, найбільш творчо, яскраво, доступно, традиційно і цілісно представлені у фольклорі. Колективний спів тут виступає показником вказаних ознак цілісності.

На користь такої цілісності вказує навіть строкатість жанрових класифікацій дитячого фольклору, розбудованих за різними принципами: віковим, побутовим, генетичним, функціональним, синтетичних та еклектичних побудов, функціонально-віковий. Більшість 3 них через різні причини асимілювалися з дорослих жанрів чи навіть давніх культових уявлень. Так, дитячі календарні твори, втративши первинну магічну функцію, трансформувавши окремі елементи обрядової поезії, набули рис розважальності, жартівливості. Наприклад, колядки, традиційно виконувані дітьми, є різновидами традиційних колядок і шедрівок, далеко відходять від канонічних зразків, впроваджуючи нові, «прокреаційні концепції людського життя в індивідуальній і колективній формах» $(8,89)$, відтворюючи християнську, язичницьку, побутово-ігрову образність, що відбивається на музично-мовних засобах.

У смисловому полі дитячого фольклору спеціально виділяються специфічні ознаки колективності та ігрової природи - обидві виступають маркерами й сучасного дитячого хорового співу у його існуючих жанрово-стилістичних і тембрально-складових форматах. Ознака колективністі базується на кількох позиціях.

Н. Купріна доводить, що «групові музично-ігрові форми діяльності визнаються психологами та педагогами як домінантні у період дитинства ... і необхідні для становлення особистості, здорової у фізичному, психічному і духовному сенсах (виділено нами. - Л. Д.)» [5, 27]. Адже самий процес взаємодії учасників колективного художньотворчого акту (один з одним та з художніми образами навколишньо- 
го світу) забезпечує за допомогою специфічних засобів практичну включеність особистості «в освоєння моделей відповідальної і позитивної поведінки», «гармонійної взаємодії в системі «людина - природа (ширше, міфологічно-релігійний компонент. - Л. Д.) суспільство»», а фольклорна традиція «з семіотичної точки зору є передачею по каналах усної комунікації культурно, соціально (та сакрально. Л. Д.) значущих повідомлень, тобто «культурних текстів» у широкому смислі слова» і у дописемну епоху це - «єдиний спосіб збереження, передачі і відтворення інформації» [5, 45, 18]. Сама технологія усної традиції будується на безпосередньо-контактному типі комунікації, коли ії «молекулою» є передача тексту «з рук в руки» (слухачам і учасникам спільного виконання), «без «технічного посередника» між ними, будь то будь-який носій фіксованого повідомлення - від папірусу до лазерного диска» [12]. Головна властивість фольклору (усна природа) виникає зі способу його існування - передача і зберігання текстів «можливі тут тільки при безпосередньому спілкуванні людей». Причому колективне не заступає тут особистісто-індивідуальному, бо «смисловий, у тому числі міфологічний, простір усної традиції - свого роду гіпертекст з усіма його характерними рисами: незавершеністю, інтертекстовістю і інтерактивністю. Вибір індивидуальних стратегій в ньому... являє собою свого роду семіотичну гру з наявними смислами і... визначається особистими стратегіями і бажаннями» $[18,245]$. Отже фольклорний колективний дитячий спів, як форма поліхудожньої ігрової діяльності, організованої за законами побутування мистецтва усної традиції, забезпечує включення особистості дитини до «механізмів психорегуляції, соціалізації і емоційнодіяльнісного переживання світоглядних... цінностей» $[18,44]$. Так відбувається складний процес інтеріоризації світоглядних цінностей у дитячому фольклорі.

Можна також припустити, що психологічно й відчутно-звуково спів малечі має бути «підсиленим» кількісним потовщенням лінії i, безсумнівно, виховує майбутніх членів громади у відчутті ії спільності-цілісності. Така колективна гетерофонність звучання виражає й загальні принципи співочої фольклорної (первинної) гетерофонії як «живої» єдності з вишуканою можливістю свободного розцвічування основної мелодійної лінії, що відбиває діалектичні властивості переважно общинного формата «народної філософії» (міфології, світувідчуття) з певними короткими (не «по-справжньому» сольними) «виступами» окремих «героїв»-голосів, що у музично-мовному вира- 
женні постає вільним сходженням/розходженням до унісонів та від них. Але ця індивідуальна імпровізація здійснюється за здавна сталими схемами, на основі колективно вироблених засобів художньої виразності. Індивідуальне начало, так само як і колективне, має місце на всіх етапах розвитку фольклору. Воно приймає різноманітні форми вираження і в історичній хронології виявляє тенденцію до посилення і активізації, передусім у специфічних епічних жанрах. Лінеарно-гетерофонний спів визначався як сукупність-єдність невід'ємних складових - музики і слова, а музична ритмована та звуковисотна інтонаційність значно підсилює значущість, виразність та семіотичність поетичного слова. Накладання вербального на музичне у дитячому співі створює додаткову систему ментально-світоглядних цінностей.

Специфічні особливості традиційної усної культури, як синкретичного єднання різних видів мистецтв на основі вітальності засобів виразності, тобто безпосередньої пов'язаності з тілесними відчуттями і життєдіяльністю людини, актуалізують інтонаційно-голосовий і руховий компоненти. «Природно-інтонуємий звук і супроводжуючий його тілесний рух - природні адаптаційні механізми, які дані людині природою, є головними «інструментами» матеріалізації емоційного світу людини, регуляції її станів і поєднують єдиними законами людину з навколишнім фізичним і соціокультурним простором» $[5,25]$. Синкретичне поєднання у фольклорному колективному співі-грі мовного інтонування та руху «слугувало формою емоційно-діяльнісного переживання і набуття людиною через «долучаючу ідентифікацію» (В. П. Іванов) духовних цінностей, накопичених колективним досвідом» [там само] (особливо важливих у виховному процесі дитини). Спів і танцювальні рухи у колективному виконанні активно включали дитину до процесу «переживання смисложиттєвих ідей і поглядів, які є значущими для цієї спільноти» [5, 25]. Людський голос (як і рухи) фізіологічний за природою і «в такому сенсі «відприродний», всі культурні функції (і вся культурна інформація) надбудовуються на цьому даному природою механізмі; усне слово (на відміну від книжкового) не може бути відокремлене від живого носія, це завжди (і тільки) звучне слово. Як посередник між природним початком в людині, з одного боку, і культурним, з іншого, голос має медіативну функцію» [11].

Ще одна сфера впливу на ознаку колективності у фольклорі вбачається з боку християнської традиції, щільно переплетеної у слов’янському просторі з іншими сферами впливів (зокрема, язич- 
ницько-міфологічною). Значущими тут виступають явище і якість соборності, як органічної, не-зовнішньої єдності особистей із збереженням власної індивідуальності і свободи [16] та колективний спів ангелів, славлячих Бога на небесах. Соборно-общинне (у музичному втіленні - хорове) виступає первинним у народній свідомості - як прояв сукупного людського суб'єкта, колективно-соборного «Ми», що спрямовує установки індивіда і має бути увібраним «з молоком матері» у виховному процесі. У християнській музичній традиції траекторія розвитку складається від первинної гетерофонії-потовщення - через церковну монодію - до багатоголосного хорового співу. У першому випадку діти могли брати участь у приналежності до соборного загалу парафіян, не виділяючись в окремий шар (в родині і общині); другий передбачав, передусім, дорослих хористів-професіоналів; третій у тембрально-вертикальній цілісності створював умови для визнання специфіки дитячого (насамперед, хлопчакового) співу як символічно-звукового втілення чистоти, щирості й близькості до Христа. У пізніших - постхристиянських - зразках дитячого фольклору хоровий (колективний) спів і зосередився у жанрах календарно-церковних - перш за усе, в колядках та щедрівках.

Цікаво, що С. Лойтер [7] вказує на відсутність у дитячому фольклорі традицій епічного сольного сказительства на користь колективного дитячого виконання, що пов'язане з функційною специфікою народної педагогіки, в якій дитинство традиційно не розглядається як специфічний окремий світ, а сприймається у дуалізмі розумінь про «нерозвинену дорослість», підготовку до дорослого життя (включаючи трудові, природно-магічні і релігійні, соціально-психологічні його майбутні реаліі) та про порубіжжя, одночасну приналежність дитини потойбіччю (з якого вона нещодавно прийшла) і реальному життю (де вона має стати дорослою). До того ж оволодіння солістом-сказителем складним комплексом знань і умінь, технікою та технологією виконання (часто додатково й інструментального супроводу), триваюче усе творче життя вдосконалення і засвоєння з різних джерел нових текстів потребують не тільки специфічного таланту, але й років професійного і духовного вдосконалення. Натомість Б. Путилов стверджує, що такий співак «не може з'явитися «зі сторони... Пробудження може здійснитися ... частіше - в ранні дитячі роки. Дитинство (від 5 років. - Л. Д.) - нормальний етап початку прилучення до епічного мистецтва» $[14,13]$. I все ж таке прилучення - це ще не повноцінне, «на широку публіку» - общину, виконавство, яке «вбирається в різ- 
номанітні ритуальні форми» $[14,80]$ і вимагає суворо індивідуального підходу: діти виростають, формуються в епічному середовищі, разом 3 дорослими слухають казок, засвоюють зміст епосу, переймаються його духом, але це «не їхній» жанр, його серйозність вимагає «повноцінної дорослості» та професіоналізму. Учні-сказителі «відшліфовували» свою майстерність спочатку на слухачах-однолітках, але попереду безперечно брали участь у колективних формах співу.

Ігрова природа дитячого фольклору (характеристики якої не обминає жодне дослідження) виступає важливим, необхідним і цілком природним мостом фольклору та дитячості. Практично усі відомі види дитячого пісенного фольклору можуть бути названі ігровими і колективними. За допомогою пісні визначаються «ролі учасників гри... виражаються загальні, вкрай безпосередні емоції; досягається одночасність і послідовність дії» $[6,58]$. Творчо-продуктивні інтенції гри з іманентними позитивними векторами сприйняття, властивостями співпричетності (партиципації) та співпереживання (емпатії) виявляються (і відточуються) у колективних формах. Н. Белопольська стверджує, що «властивості хороводних ігор можуть надавати цілісний позитивний вплив на розвиток комунікативних навичок дітей» $[1,131]$. Жанр хороводу представляє дивовижний тип комунікації: його синкретизм складається з пісні, гри, танцювально-ритмізованого руху, елементів драматичної дії з обов'язковим спільним виконанням, сюжет якої, як правило, відбивається в пісні. Комунікація відбувається на кількох рівнях мовного спілкування - емоційному, афективному, тактильному. Вчені відзначають, що у спілкуванні дітей між собою майже в десять разів більше експресивно мімічних проявів та підкреслено яскравих виразних інтонацій, ніж у спілкуванні дитини і дорослого [2]. Дитячі хороводні ігри відповідають принципу системності, бо «орієнтовані на розвиток та інтеграцію психічних процесів, спрямовані на формування навичок побутової та соціальної поведінки, дозволяють цілісно впливати на розвиток передумов формування комунікативних навичок» $[1,137]$. Цінним $є$ й той факт, що дитина фактично може бути включена до ігрової ситуації «на будь-якому етапі свого розвитку і в міру своїх сил і можливостей інтегрована до групи однолітків» [там само].

Висновки. Категорії колективності, гри, цілісності, а також дитинства, дитячості виступають у дитячому фольклорі (поряд з синкретизмом, утилітарністю, символізмом, образністю, декоративністю і традиційністю - за визначенням В. Василенка, Т. Воробйової, В. Во- 
ронова, М. Некрасової, С. Рождественської та ін.) тими основними концептами, які визначають його зміст, розвиток, міфологічні й виховальні засади, музично-мовні засоби.

Історична традиція «спускання» до сфери дитячого користування обрядово-ритуальних форм дорослих фіксує «оптимальні стратегії взаємодії з навколишнім світом, що передаються наступним поколінням у відносно незмінному ігровому інваріанті» і $€$ «економною формою накопичення і трансляції культурного досвіду, освоєння якого може виступати умовою збереження культурної пам'яті в межах соціальної групи і розвитку окремої особистості» $[19,13]$. Одночасно традиційна дитяча гра тісно пов’язана з конституцією суб'єктивності, забезпечуючи розвиток особистості.

Таким чином, дитинство як архетипове начало людського світосприйняття, відкрите мистецтвом і науковими виходами романтизму, 3 породженим ними епіфеноменом «дитячості», глибинно перегукується з іншим архетиповим началом - міфологічним за природою фольклором.

\section{СПИСОК ЛІТЕРАТУРИ}

1. Белопольская Н. Хороводные игры как метод коммуникативного развития дошкольников с нормативным и нарушенным психическим развитием / Н. Белопольская, О. Рубан // Социальная психология и общество. 2012. - № 4. - С. 130-140.

2. Галигузова Л. Ступени общения: от года до шести / Л. Н. Галигузова, Е. О. Смирнова. - М. : Интор, 1996. - 160 с.

3. Дитячий фольклор / Упоряд. і передм. Г. В. Довженок ; іл. худож. Ю. І. Криги. - К. : Дніпро, 1986. - 304 с.

4. Капица Ф. С. Русский детский фольклор : [учеб. пособие] / Ф. С. Капица, Т. М. Колядич. - М. : Флинта : Наука, 2002. - 320 с.

5. Куприна Н. Г. Эколого-эстетический подход в художественном воспитании детей : автореф. дис. ... докт. пед. наук : спец. 13.00.01 «Общая педагогика, история педагогики и образования» / Н. Г. Куприна. - М., 2008. $-52 \mathrm{c}$.

6. Литвин Э. Песенные жанры русского детского фольклора / Э. С. Литвин // Советская этнография. - 1972. - № 1. - С. 58-67.

7. Лойтер С. М. Русская детская литература XX века и детский фольклор: проблемы взаимодействия : автореф. дис. ... д-ра филолог. наук : спец. 11.01.01 «Русская литература» / С. М. Лойтер. - Петрозаводск, 2002. $-39 \mathrm{c}$.

8. Марчун О. Матеріали до вивчення дитячого фольклору : навч. посібник / О. В. Марчун. - К. : Київський університет, 2010. - Ч. 1. - 201 с. 
9. Мельников М. Русский детский фольклор / М. Н. Мельников. - М. : Просвещение, 1987. - 100 с.

10. Мнацакян Л. А. Темброакустическая модель как инструмент исследования фольклора и композиторского творчества : дис. ... канд. искусствоведения : 17.00 .02 / Л. А. Мнацакян. - Краснодар, 2014. - 204 с.

11. Неклюдов С. Звучащее слово в фольклоре / С. Ю. Неклюдов [Электронный ресурс]. - Режим доступа : http://www.ruthenia.ru/folklore/ neckludov13.htm

12. Неклюдов С. Культурная память в устной традиции: историческая глубина и технология передачи / С. Ю. Неклюдов [Электронный ресурс]. Режим доступа : http://www.ruthenia.ru/folklore/neckludov78.htm

13. Осорина М. В. Фольклор детский / М. В. Осорина // Свод этнографических понятий и терминов. - М. : Наука, 1991. - Вып. 4 : Народные знания. Фольклор. Народное искусство. - С. 140-142.

14. Путилов Б. Эпическое сказительство : Типология и этническая специфика / Б. Н. Путилов. - М. : Восточная литература, 1997. - 295 с. - (Исследования по фольклору и мифологии Востока).

15. Росовецький С. К. Український фольклор у теоретичному висвітленні : посібник [для університетів]. - К. : Вид-во Українського фітосоціологічного центру, 2007. - Ч. 2 : Жанри. - 623 с.

16. Соборность // Новейший филос. Словарь [Электронный ресурс]. Режим доступа : https://translate.google.com.ua

17. Угрюмова М. Лингвокультурологический портрет ребенка в говорах Среднего Приобья : автореф. дис. ... канд. филолог. наук : спец. 10.02.01 «Русский язык» / М. М. Угромова. - Томск, 2014. - 22 с.

18. Христофорова О. Упавшая крыша и дочь колдуна, ил о коллективности представлений и индивидуальности толкований / О. Б. Христофорова // Запретное / допускаемое / предписанное в фольклоре. - М. : РГГУ, 2013. C. $228-248$.

19. Черная А. Развитие личности в традициях игровой культуры : автореф. дис. ... Д-ра психол. наук : спец. 19.00.13 «Психология развития, акмеология» / А. В. Черная. - М.. 2007. - 44 с.

\section{REFERENCES}

1. Belopol'skaya, N., \& Ruban, O. (2012). Round dance games as a method of communicative development of preschool children with normative and disturbed mental development. Social psychology and society. 4. 130-140 [in Russian].

2. Galiguzova, L. N., \& Smirnova, E. (1996). Steps of communication: from one year to six. Moskva: Intor. 160 [in Russian].

3. Dovzhenok, G. V. (Eds.). Child Folklore. (1986). Kyiv: Dnipro, 1986. 304 [in Ukrainian].

4. Kapitsa, F. S., \& Kolyadich, T. M. (2002). Russian children's folklore. Moskva: Flint: Science. 320 [in Russian]. 
5. Kuprina, N. G. (2008). Ecological and aesthetic approach in the artistic education of children. Extended abstract of candidate's thesis. Moskva: The Institute art education of the Russian Academy of Education

6. Litvin, E. (1972). Song genres of Russian children's folklore. Soviet ethnography. 1. 58-67 [in Russian].

7. Loiter, S. M. (2002). Russian children's literature of the XX century and children's folklore: problems of interaction. Extended abstract of doctor's thesis. Petrozavodsk: KGPU [in Russian].

8. Marchun, O. V. (2010). Materiali before vyvchennya dityachogo folklore. Kyiv: Kyiv University. 1. 201 [in Ukrainian].

9. Melnikov, M. N. (1987). Russian children's folklore. Moskva: Enlightenment. 100 [in Russian].

10. Mnatsakyan, L. A. (2014). Temroakusticheskaya model as a tool for the study of folklore and composer creativity. Candidate's thesis. Krasnodar KGUKI [in Russian].

11. Neklyudov, S. Yu. (2000). Sound word in folklore. Retrieved from http:// www.ruthenia.ru/folklore/neckludov13.htm

12. Neklyudov, S. Yu. (2003). Cultural memory in the oral tradition: historical depth and technology of transmission. Retrieved from http://www.ruthenia.ru/folklore/neckludov78.htm

13. Osorina, M. V. (1991). Folklore for children. Code of Ethnographic Concepts and Terms. Moskva: Science. 4. 140-142 [in Russian].

14. Putilov, B. N. (1997). Epic story: Typology and ethnic specifics. Moskva: Eastern Literature. 295 [in Russian].

15. Rosovetsky, S. K. (2007). Ukrainian folklore at the theoretical level. K.: View of the Ukrainian fetociological center. 2. 623 [in Ukrainian].

16. Sobornost '. The Newest Philosophy. Dictionary Retrieved from https:// translate.google.com.ua

17. Ugryumova, M. M. (2014). Lingvokulturologichesky portrait of the child in the dialects of the Middle Ob. Extended abstract of candidate's thesis. Tomsk: TGU [in Russian].

18. Khristoforova, O. B. (2013). The Fallen Roof and the Witch's Daughter, or the Collectivity of Representations and the Individuality of Interpretations. Forbidden / tolerated / prescribed in folklore. Moskva: RGGU. 228-248 [in Russian].

19. Chernaya A. V. (2007). Development of the individual in the traditions of game culture. Extended abstract of doctor's thesis. Moskva : MPGU [in Russian].

Стаття надійшла до редакції 14.06.2016

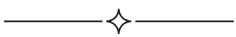

